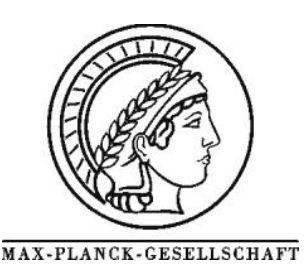

Journal of Catalysis 269 (2010), 351-358

\title{
Characterization of Catalysts in Their Active State by Adsorption Microcalorimetry: Experimental Design and Application to Sulfated Zirconia
}

\author{
S. Wrabetz, X. Yang, G. Tzolova-Müller, R. Schlögl, F.C. Jentoft* \\ Fritz Haber Institute of the Max Planck Society, Department of Inorganic Chemistry, \\ Faradayweg 4-6, D-14195 Berlin, Germany
}

\begin{abstract}
* Corresponding author: e-mail fcjentoft@ou.edu, new address: Chemical, Biological, and Materials Engineering, University of Oklahoma, 100 East Boyd Street, Norman, OK 73019-1004, USA
\end{abstract}

Received 4 August 2009; revised 12 November 2009; accepted 18 November 2009. Available online 23 December 2009.

\begin{abstract}
A method to characterize the surface sites of catalysts in their active state by adsorption microcalorimetry was developed. A calorimeter cell was used as a flow-type reactor, and the skeletal isomerization of $n$-butane $(1 \mathrm{kPa})$ at $378 \mathrm{~K}$ and atmospheric pressure proceeded at comparable rates and with the same states of induction period, maximum and deactivation phase as in a tubular reactor. The reaction was run for selected times on stream and after removal of weakly adsorbed species, $n$-butane or isobutane were adsorbed at $313 \mathrm{~K}$. The surface of activated sulfated zirconia was characterized by at least two different sites for $n$-butane adsorption, a small group of sites (about $20 \mu \mathrm{mol} \mathrm{g}^{-1}$ ) that yielded heats of $50-60 \mathrm{~kJ}$ $\mathrm{mol}^{-1}$ and sites that were populated at higher pressures (above about $5 \mathrm{hPa} n$-butane) and yielded heats of about $40 \mathrm{~kJ} \mathrm{~mol}^{-1}$. The strongly interacting sites disappear during the induction period and are proposed to be the sites where the isomerization reaction is initiated.
\end{abstract}

Keywords: sulfated zirconia, isomerization, microcalorimetry, $n$-butane, isobutane, adsorption isotherm

\section{Introduction}

Sulfated zirconia is an active catalyst for the skeletal isomerization of small alkanes [1-3]. Its activity at temperatures as low as room temperature [1] has evoked commercial interest. In the past decades, extensive efforts have been devoted to the investigation of those bulk structural and surface properties of sulfated zirconia that affect the catalytic activity [4,5]. It has been demonstrated that the zirconia phase composition, the sulfur content, the surface area, and the addition of a second metal oxide component as a promoter are all properties that influence the maximum activity of this type of catalyst [1-7]. Many of these properties depend on details of the preparation procedure such as the wet-chemical association of the components and formation of the solid [8], the calcination conditions [9,10], or post-synthesis treatments such as grinding or pressing [11]. However, the characterization data of the calcined catalyst material do not explain the mechanism of alkane conver- sion and the behavior during reaction. Almost all types of sulfated zirconia catalysts, regardless of promotion with iron or manganese cations [6-10], exhibit a multi-phase activity profile with time-on-stream, which consists of an induction period, a maximum in activity, rapid deactivation and almost steady long-term performance. This observation suggests a continuous change of the catalyst under reaction conditions or, in other words, a modification of the number or nature of the surface sites. The formation of active sites, accumulation of intermediates [12,13] and, at a later stage, of carbonaceous deposits on the surface [14-17] has to be considered. A number of materials are known to become active only under reaction conditions, for example vanadium pyrophosphate catalysts for butane to maleic anhydride oxidation [18] and copper-zinc catalysts for methanol synthesis [19]. Information on the state of the catalyst surface sites during the individual phases of a reaction profile would thus be valuable. 
One way to characterize the sites of a catalyst is through adsorption of probe molecules. The surface of sulfated zirconia has been extensively probed for its acid-base properties [20] and also the interaction with $n$-butane and isobutane has been investigated [21]. Detailed reports are available on the effect of the activation conditions on catalytic performance [22-24]. However, little is known about the fate of the sites once the catalyst is exposed to the feed. An experimental method is required that allows (i) conducting the catalytic reaction with concomitant gas phase analysis to monitor the state of the catalyst and (ii) subsequent "in situ" characterization of the sites through adsorption without alteration of the catalyst state, by, for example, exposure to air.

Adsorption microcalorimetry is a method to measure the small quantity of heat released during the adsorption of probe molecules on solid surfaces. Typical applications are the characterization of the acid strength of zeolites or heteropolyacids by adsorption of basic probe molecules such as $\mathrm{NH}_{3}$ and $\mathrm{CO}$ [25-28]. Adsorption microcalorimetry has been employed to determine the number and strength of acidic and basic sites on sulfated zirconia by using $\mathrm{NH}_{3}$ [21], pyridine [29,30] or $\mathrm{CO}_{2}[31,32]$ as probes. Similar microcalorimetric investigations have been carried out on $\mathrm{NH}_{3}$ adsorption on tungstated zirconia [33]. The reported measurements show that sulfated zirconia materials possess acidic sites of moderate strengths. These results do not explain the origin of the activity for low-temperature alkane isomerization. Also for other acidic materials such as zeolites, catalytic performance could not be correlated to heats of adsorption of basic probe molecules [34,35]. The reason for this mismatch could be that the characteristics of the probes, for example, $\mathrm{NH}_{3}$ or pyridine, differ vastly from those of the reactants, which in our case are light alkanes. Thus, a set of sites may be probed that is not relevant to the catalytic reaction of interest. To be able to correlate the microcalorimetric results and the catalytic activity, a probe molecule similar to the reactant, or even the reactant itself should be employed. For example, Coker et al. [36] used benzene and benzene derivatives as probes in a calorimetric investigation on the Brönsted acid sites that catalyze the disproportionation of ethylbenzene. In case of alkane isomerization, adsorption of the isoalkane is also of interest to test whether the product desorption can be rate-limiting.

In the present work an apparatus and a procedure are developed that allow the characterization of the sites of a catalyst in any active state along the reaction profile through adsorption microcalorimetry. The cell of a calorimeter is used as a flow reactor, wherein the catalytic reaction, in this case of $n$-butane isomerization on sulfated zirconia, is carried out. After defined times on stream, when the activity has reached a desired stage, the feed flow (of $n$-butane) is stopped and the cell evacuated, and the calorimetric measurement is performed with $n$ - or isobutane as probe molecules. In this way, the sites interacting with light alkanes can be identified at various active states of the catalyst.

\section{Experimental procedure}

\subsection{Materials}

Two types of sulfated zirconia were employed. One material was prepared through precipitation from zirconyl nitrate solution, sulfation of the dried precipitate with ammonium sulfate, and calcination at $873 \mathrm{~K}$ for $3 \mathrm{~h}$. The procedure is described in detail in [8]. The sulfate content of this material sample was $0.94 \mathrm{mmol} \mathrm{g}^{-1}\left(9.02 \mathrm{wt} \% \mathrm{SO}_{4}{ }^{2-}\right)$, and the BET surface area was $100 \mathrm{~m}^{2} \mathrm{~g}^{-1}$. The second material was obtained through calcination of a commercially available sulfated hydrous zirconia (MEL Chemicals XZO 682/01, 5-6 wt.\% $\mathrm{SO}_{3}$ on $\mathrm{ZrO}_{2}$ content) at $823 \mathrm{~K}$ for $3 \mathrm{~h}$ and was solely used for a series of experiments with varying activation temperature. The surface area of this sample was $86 \mathrm{~m}^{2} \mathrm{~g}^{-1}$.

$n$-Butane and isobutane for the calorimetry experiments were of $99.5 \%$ purity (Messer-Griesheim). $n$-Butane used in the catalytic tests was a custom mixture (Linde) containing 5\% $n$-butane (99.95\%) in $\mathrm{N}_{2}(99.999 \%)$, which was further diluted to give the reaction feed.

\subsection{Catalytic tests}

A tubular fixed bed plug flow reactor with $13 \mathrm{~mm}$ inner diameter was filled with $500 \mathrm{mg}$ of catalyst powder. The material was activated for $1.5 \mathrm{~h}$ at $723 \mathrm{~K}$ in a flow of $50 \mathrm{ml} \mathrm{min}^{-1} \mathrm{~N}_{2}$. The reaction temperature was $378 \mathrm{~K}$, and the total flow was $80 \mathrm{ml} \mathrm{min}^{-1}$ (NTP) of a $1 \% n$-butane in $\mathrm{N}_{2}$ mixture at 0.1 MPa. A Perkin Elmer Autosystem gas chromatograph, equipped with a J\&W Scientific CSAlumina column $(30 \mathrm{~m} \mathrm{x} 0.530 \mathrm{~mm})$ and a flame ionization detector was used for analysis of the reactor effluent streams.

\subsection{Microcalorimetry}

A SETARAM MS70 Calvet calorimeter was combined with a custom-designed high vacuum and gas dosing apparatus, which has been described in detail [37]. The dosing volume is $139 \mathrm{ml}$, and an absolute pressure transducer (MKS Baratron type 121) measures pressure variations of $0.06 \mathrm{hPa}$ in this volume (provided the room temperature does not vary by more than $\pm 1.5 \mathrm{~K}$ ), so that, as a conservative estimate, amounts as small as $0.05 \mu \mathrm{mol}$ can be dosed into the sample cell. Powders are difficult to handle under vacuum conditions and thus the samples were lightly pressed into wafers, which were cut into small pieces. The sieve fraction with diameters between 0.40 and 0.60 $\mathrm{mm}$ was used for all experiments inside the calorimetric cell. An all-metal cell was employed as described in [38], but without the basket-like insert. 


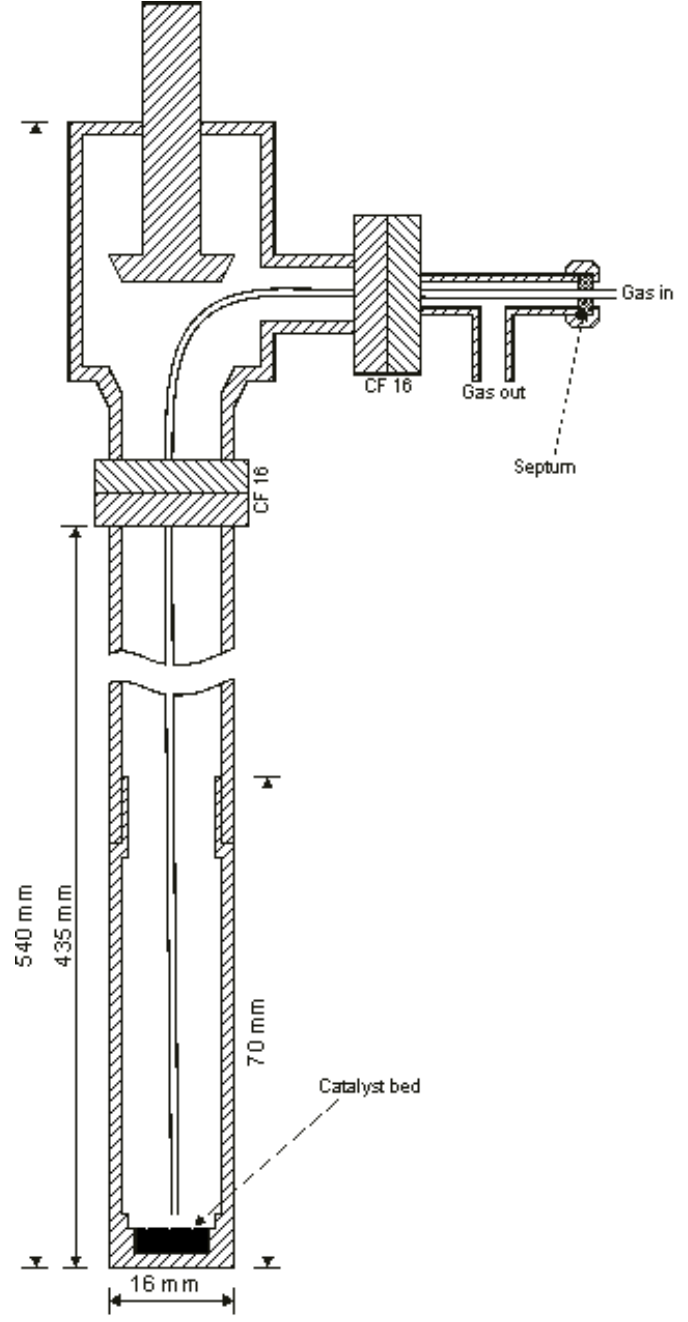

Fig. 1: Drawing of calorimeter call modified for flow reactor operation. A capillary is inserted into the cell to lead reactant onto the catalyst bed.

Activation for a standard calorimetry experiment was conducted inside the calorimeter cell. After evacuation to a pressure $\leq 10^{-6} \mathrm{hPa}$, the cell was heated to the desired temperature of 473,573 , or $723 \mathrm{~K}$, held at this temperature for $1.5 \mathrm{~h}$ and then cooled to room temperature. The cell was then transferred into the calorimeter and heated to the adsorption temperature of $313 \mathrm{~K}$. $n$-Butane or isobutane were introduced into the initially evacuated cell, and the pressure evolution and the heat signal were recorded for each dosing step. The adsorption isotherm was derived from the dosed amount and the equilibrium pressure (in comparison to an empty cell), and the differential heats of adsorption were calculated by converting the signal area into a heat by using the calorimeter's calibration factor and then dividing the heat by the number of molecules adsorbed in this step. All data sets (consisting of one isotherm and the corresponding heats of adsorption) were obtained by treating a fresh sample.

To analyze catalysts in their active state, the calorimeter cell was used as a flow reactor. As shown in Figure 1 , a stainless steel capillary was introduced through a sep- tum at the top of the sample cell, guided through the tubular part, and brought close to the surface of the catalyst bed of $500.0 \mathrm{mg} \mathrm{SZ}$ at the bottom of the cell. By connecting the capillary to a feed delivery system, the sample could be exposed to various gas flows, whereby the composition could be switched between an inert gas stream and a reactant gas mixture. The cell was purged with $50 \mathrm{ml} \mathrm{min}^{-1} \mathrm{~N}_{2}$ (NTP), placed into the isothermal zone of a tubular oven, heated to $723 \mathrm{~K}$ for $90 \mathrm{~min}$ and cooled to the reaction temperature of $378 \mathrm{~K}$. The reaction feed was $50 \mathrm{ml} \mathrm{min}{ }^{-1}$ (NTP) of a 1 vol.\% $n$-butane in $\mathrm{N}_{2}$ mixture. The composition of the reacted gas mixture was analyzed with on-line GC as described above.

At selected times on stream, when the catalyst had reached a particular stage of performance along the reaction profile, the feed flow was switched off and the cell was purged with $\mathrm{N}_{2}$ at a rate of $50 \mathrm{ml} \mathrm{min}^{-1}$ for $1 \mathrm{~h}$. With the $\mathrm{N}_{2}$ flowing, the capillary was then carefully retracted through the septum until the all-metal corner valve at the top (see Fig. 1) could be closed. After closing the valve, the tee connector with the gas inlet and outlet was removed at the CF16 flange, and the cell was connected to a small recipient with a turbomolecular pump (Balzers). The recipient and the connection were evacuated up to the corner valve, which was then opened. The sample was degassed at $313 \mathrm{~K}$ for $48 \mathrm{~h}$, heated to $378 \mathrm{~K}$ under dynamic vacuum, and kept at this temperature for $1.5 \mathrm{~h}$. The final pressure in the degassed cell was typically $7 \times 10^{-7} \mathrm{hPa}$. After the cell had cooled, the corner valve was closed and the cell was detached from the recipient, placed into the calorimeter and connected to its vacuum and gas-dosing apparatus.

\section{Results}

\subsection{Validation of the use of the calorimeter cell as a fixed bed flow reactor and catalytic data}

The first consideration with respect to carrying out reactions in the calorimeter cell as described in the experimental section was how the data obtained with this "flowover" rather than flow-through construction compare to those obtained with a standard fixed-bed once-through plug-flow reactor. Potential diffusion limitation was evaluated using the Weisz modulus:

$$
\Psi^{\prime}=L_{c}^{2} \frac{r_{\text {observed }}}{D_{n-b u t / N_{2}}^{e} c_{n-b u t}}
$$

The entire bed was modeled as a single large catalyst particle with gas access only from the top. The characteristic length was thus considered to be equal to the height of the layer in the calorimeter cell, that is, $\mathrm{L}_{\mathrm{c}}=3.8 \mathrm{~mm}$. The highest observed rate $r_{\text {observed }}$ of $40 \mu \mathrm{mol} \mathrm{g} \mathrm{g}^{-1} \mathrm{~h}^{-1}$ or 11.1 nmol g ${ }^{-1} \mathrm{~s}^{-1}$ (assuming a sulfated $\mathrm{ZrO}_{2}$ density of $5.5 \mathrm{~g} \mathrm{~cm}^{-}$ ${ }^{3}$ ) was used. The $n$-butane concentration $\mathrm{c}_{\mathrm{n} \text {-but }}$ was 1 vol\% 


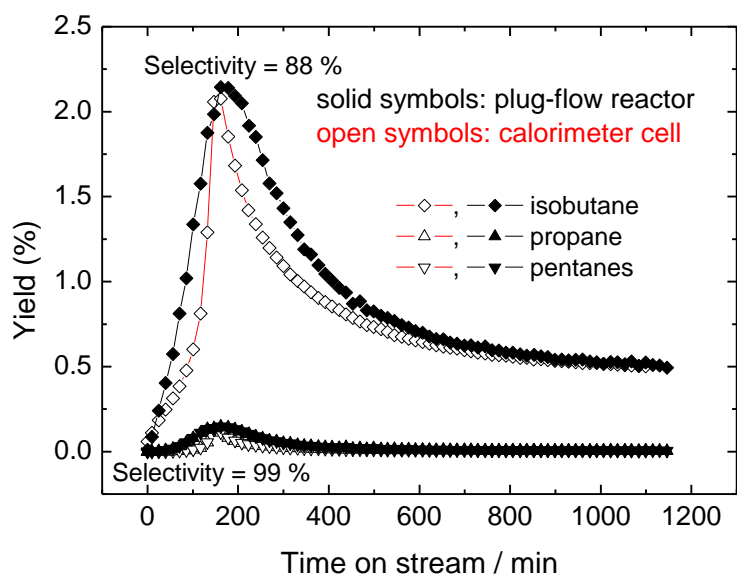

Fig. 2: Comparison of $n$-butane isomerization data obtained in a tubular once-through plug-flow fixed bed reactor and in the calorimeter cell (Fig. 1). Conditions: catalyst mass $500 \mathrm{mg}$ of calcined MEL Cat. XZO 682/01; reaction temperature $378 \mathrm{~K}$; total flow 50 $\mathrm{ml} \mathrm{min}{ }^{-1} 1.0 \mathrm{vol} \% n$-butane/ $\mathrm{N}_{2}$ feed (NTP); total pressure $0.1 \mathrm{MPa}$.

or $0.33 \mu \mathrm{mol} \mathrm{cm} \mathrm{cm}^{-3}$. The diffusivity was calculated according to the method and with the data provided by Hirschfelder et al. [39] to be $\mathrm{D}_{n \text {-but/N2 }}=0.15 \mathrm{~cm}^{2} \mathrm{~s}^{-1}$. To estimate void fraction and tortuosity, particles of spherical geometry with a diameter of $0.5 \mathrm{~mm}$ were assumed. A value of 0.74 was obtained for the Weisz modulus, which for a reaction order of 1.5 [40] corresponds to an effectiveness factor of about 0.75 . Hence, diffusion limitations could not a priori be excluded. However, the reactant gas is not stagnant but is blown onto the bed through the capillary.

Figure 2 shows the results of reaction tests in the modified calorimeter cell and in a tubular fixed-bed plugflow glass reactor with an inner diameter of $13 \mathrm{~mm}$. The main product of $n$-butane conversion in both reactors was the product of skeletal isomerization, isobutane. Propane and pentanes were observed as side products. The isobutane selectivity was comparable in both reactors; it decreased with increasing total conversions, and reached its lowest level of $88 \%$ at the conversion maxima. The performance of the SZ catalyst with time was also similar in both tests: the highest conversion of $n$-butane of ca. $2.5 \%$ was reached after about $150 \mathrm{~min}$, and the following deactivation phase transitioned into a "steady-state" with ca. $0.5 \%$ conversion at more than $1000 \mathrm{~min}$ on stream. This time-on-stream behavior of the activity is characteristic for $\mathrm{SZ}$ and has been repeatedly reported for $n$-butane isomerization $[6,7,11]$. The fact that the data obtained with the calorimetry cell are comparable to those obtained with a plug-flow reactor indicates that the rate is not significantly affected by diffusion limitation.

Although the two profiles are not identical the essential elements of the catalytic behavior of sulfated zirconia are observed also in the calorimeter cell. The induction period, the maximum of activity and the deactivation phase, which are observable in standard fixed-bed reactors, are well exhibited by the reaction test in the modified calorime

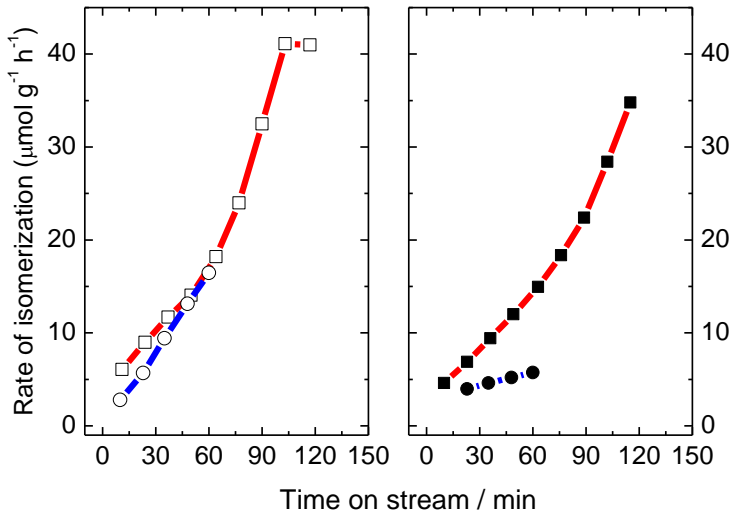

Fig. 3: Adjustment of different stages of activity of sulfated zirconia catalyst by carrying out $n$-butane isomerization in the calorimeter cell at $378 \mathrm{~K}$ and interruption of the feed at (a) $60 \mathrm{~min}$ or (b) $120 \mathrm{~min}$ on stream. Catalytic data on left panel recorded preceding $n$-butane adsorption, on the right panel preceding isobutane adsorption. Conditions: catalyst mass $500 \mathrm{mg}$; reaction temperature

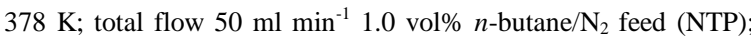
total pressure $0.1 \mathrm{MPa}$.

ter cell. It can thus be assumed that the chemical state of the catalyst along the time-on-stream profile is representative of that of a typical SZ catalyst in a standard reactor under comparable reaction conditions.

In a series of experiments, different stages of activity of the SZ catalyst were produced, whereby each time the calorimeter cell was loaded with $500 \mathrm{mg}$ of fresh SZ catalyst. The material was (i) just activated, (ii) the reaction was stopped during the middle of the induction period, or (iii) the reaction was stopped near the maximum of activity. Figure 3 shows the according isomerization data, which were well reproducible; except in one case the activity during the induction period was lower (right panel). The end points of each curve reflect the state of isomerization activity of the SZ surface when it was investigated in a calorimetric experiment. $n$-Butane was adsorbed (following the catalytic experiments shown in the left panel) to probe the interaction with the reactant, or isobutane was adsorbed (following the catalytic experiments shown in the right panel) to probe the interaction with product.

\subsection{Butane adsorption isotherms and differential heats of adsorption after activation}

Figures $4 \mathrm{a}$ and $4 \mathrm{~b}$ show the effect of the activation temperature on the adsorption of isobutane on SZ. The adsorption isotherms show that with increasing activation temperature, more isobutane adsorbs at the same partial pressure. After activation at $723 \mathrm{~K}$, there are roughly $25 \%$ more sites populated than after activation at $473 \mathrm{~K}$. The heats of adsorption indicate a homogeneous surface with just a few sites $\left(<10 \mu \mathrm{mol} \mathrm{g}{ }^{-1}\right)$ that exhibit higher heats of adsorption. After activation at $473 \mathrm{~K}$ the range of heats 

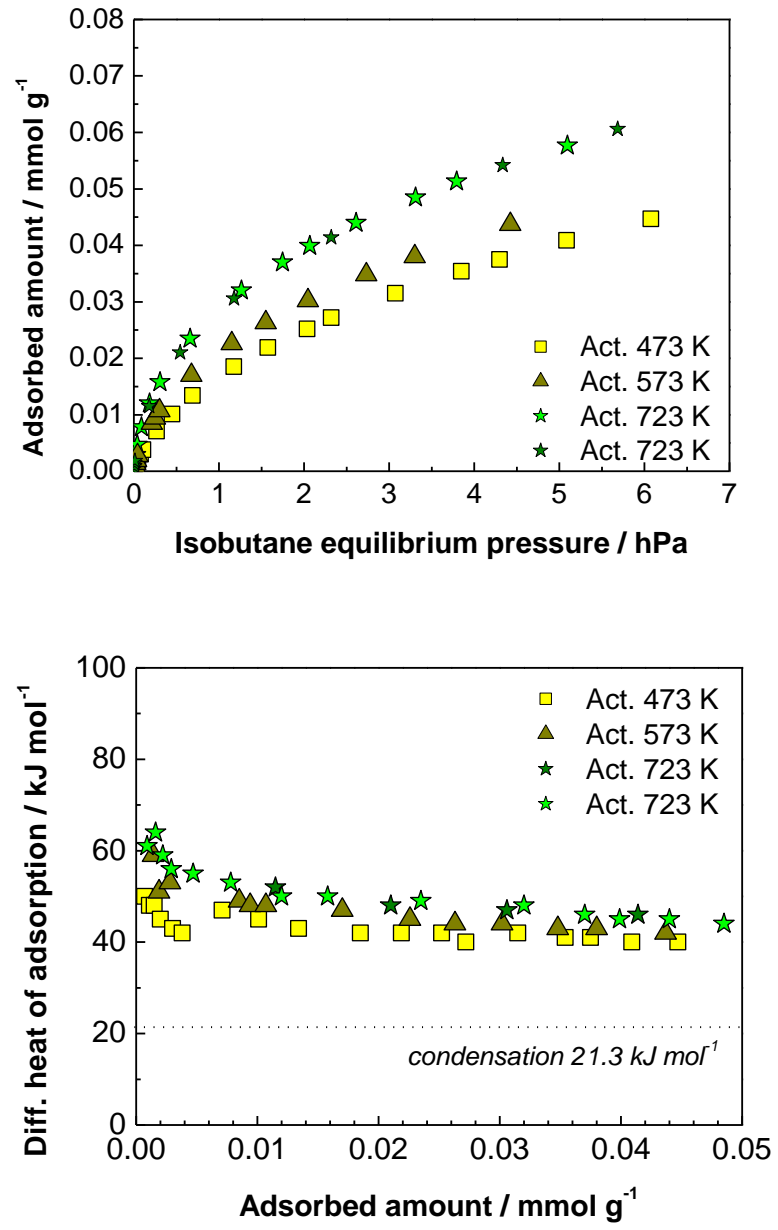

Fig. 4: Adsorption of isobutane at $313 \mathrm{~K}$ on sulfated zirconia activated at various temperatures. a) isotherm; b) differential heats as a function of coverage.

spans from $40-50 \mathrm{~kJ} \mathrm{~mol}^{-1}$; after activation at $723 \mathrm{~K}$, from 45-60 kJ mol ${ }^{-1}$. These values correspond to about 2-3 times the heat liberated upon condensation of isobutane, which is $21.3 \mathrm{~kJ} \mathrm{~mol}^{-1}$ (n-butane: $22.4 \mathrm{~kJ} \mathrm{~mol}^{-1}$ ) [41]. Repetition of one experiment (activation at $723 \mathrm{~K}$ ) shows that the isotherms and the heats of adsorption are excellently reproducible. Within the investigated range, the activation temperature that was selected for the catalytic experiment, $723 \mathrm{~K}$, leads to the surface state with the strongest affinity to isobutane. For $n$-butane, heats of adsorption of 40 to 60 $\mathrm{kJ} \mathrm{mol}^{-1}$ were obtained after activation of $723 \mathrm{~K}$.

The observed site distributions are characterized by rather small variations in the differential heats of adsorption of about $10-20 \mathrm{~kJ} \mathrm{~mol}^{-1}$. If differential heats differ only marginally sites will not be populated in a strictly consecutive manner, and steps in a site distribution will be smoothed out [42]. Thus the measured heats may reflect some averaging through simultaneous population and, in reality, the differential heats may differ more than the experiment shows.

\subsection{Butane adsorption isotherms and differential heats of adsorption at various stages of activity}

Figures $5 \mathrm{a}$ and $5 \mathrm{~b}$ illustrate how the $n$-butane and isobutane adsorption isotherms at $313 \mathrm{~K}$ vary depending on the state of the catalyst. It is obvious from these isotherms that the number of sites interacting with alkanes in the selected partial pressure range is being reduced during the induction period of about $120 \mathrm{~min}$. The loss of sites is somewhat more pronounced for the adsorption of isobutane in comparison with the adsorption of $n$-butane.

The differential heats of adsorption as a function of adsorbed amounts of $n$ - or isobutane are reported in Figures $6 \mathrm{a}$ and $6 \mathrm{~b}$. Three groups of sites are distinguished by the coverage ranges above $20 \mu \mathrm{mol} \mathrm{g}{ }^{-1}$, between 2 and $20 \mu \mathrm{mol}$ $\mathrm{g}^{-1}$, and below $2 \mu \mathrm{mol} \mathrm{g}{ }^{-1}$. At high coverage, the differential heats of adsorption are similar for fresh and active catalysts and amount to about $40 \mathrm{~kJ} \mathrm{~mol}^{-1}$, without significant differences between $n$ - and isobutane adsorption. In the intermediate coverage range, slightly higher heats of $50-60 \mathrm{~kJ} \mathrm{~mol}^{-}$ ${ }^{1}$ are observed for the fresh catalysts in comparison for the catalysts that were exposed to the feed. In the range of very low coverage the data points scattered considerably. In the $n$-butane coverage range below $2 \mu \mathrm{mol} \mathrm{g}{ }^{-1}$, the differential heats varied between 20 and $82 \mathrm{~kJ} \mathrm{~mol}^{-1}$ for activated SZ, between 32 and $62 \mathrm{~kJ} \mathrm{~mol}^{-1}$ for SZ after 60 min on stream and between 11 and $75 \mathrm{~kJ} \mathrm{~mol}^{-1}$ for SZ after $120 \mathrm{~min}$ on stream. These heats are in part lower than those observed at higher coverage. There was no clear evolution of the heats of $n$-butane adsorption in this range with time on stream. The large scatter may indicate endo- and exothermic secondary reactions on the surface of catalysts that have been started up in isomerization. However, a trend was recognizable for the adsorption of isobutane in the coverage range below $2 \mu \mathrm{mol} \mathrm{g} \mathrm{g}^{-1}$. Adsorption on the freshly activated SZ catalyst began on sites strongly interacting with isobutane, and heats up to $156 \mathrm{~kJ} \mathrm{~mol}^{-1}$ were released. The behavior of the catalyst used for $60 \mathrm{~min}$ was ambiguous with heats ranging from 20 to $100 \mathrm{~kJ} \mathrm{~mol}^{-1}$. Adsorption on SZ after use for $120 \mathrm{~min}$ was characterized by an increase of the heats of adsorption with coverage from about 13 to $51 \mathrm{~kJ}$ $\mathrm{mol}^{-1}$. A minority of sites thus changed during the course of the reaction, with an overall trend to lower heats of adsorption.

In selected cases, the gas phase in the calorimetry cell was analyzed by gas chromatography after the $n$-butane adsorption experiments, which typically stretched over several days, thus leading to very long contact times. Partial isomerization of $n$-butane to isobutane at $313 \mathrm{~K}$ in the calorimeter cell was observed for catalysts that had been only activated or also been exposed to the feed stream. The ratio of $n$ - to isobutane varied from about $3: 1$ to $0.3: 1$ for catalysts that had performed isomerization at $378 \mathrm{~K}$; and some traces of propane (in total less than $3 \%$ ) were also detected. 

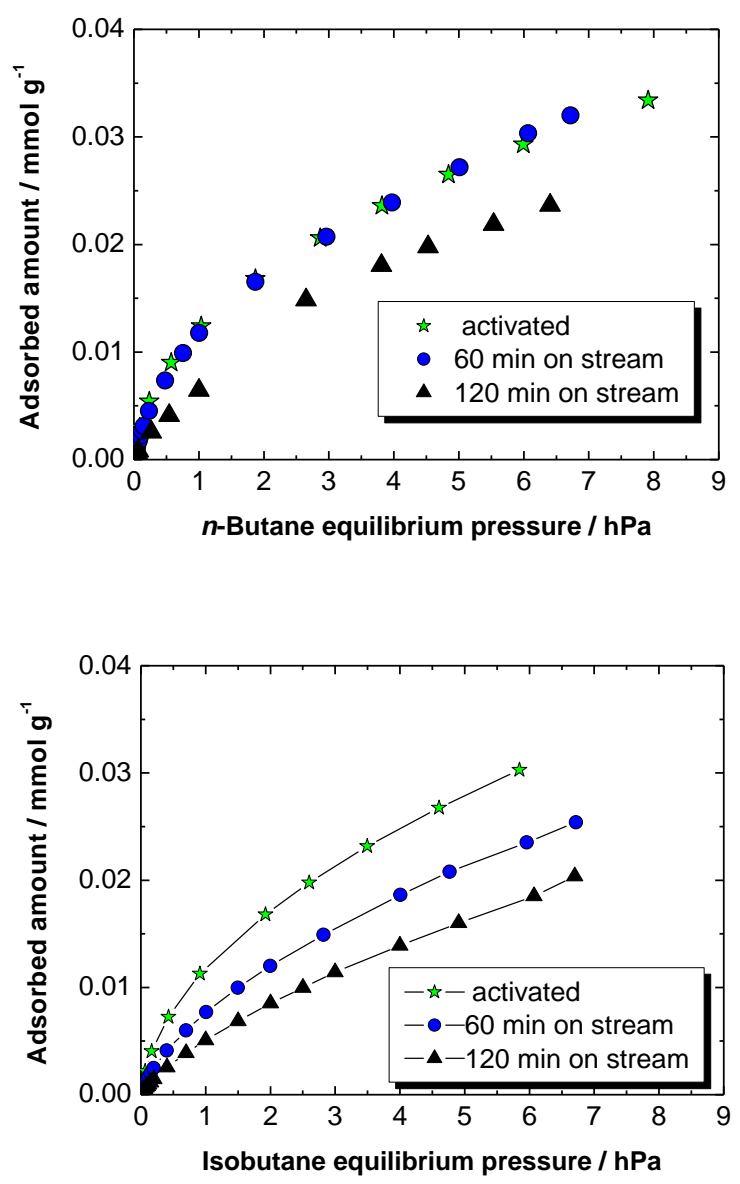

Fig. 5: Butane adsorption isotherms at $313 \mathrm{~K}$ on sulfated zirconia catalysts adjusted to various stages of activity by butane isomerization in the calorimeter cell for $60 \mathrm{~min}$ or $120 \mathrm{~min}$. a) $n$-butane adsorption; b) isobutane adsorption.

\section{Discussion}

\subsection{Analysis of isotherms}

The heats of adsorption are very similar for the majority of sites, which suggests that the sites are nearly equivalent. It was thus attempted to fit the isotherms with the Langmuir adsorption equation [43], rather than Freundlich or Temkin isotherms, which are observed when the heats of adsorption decrease with increasing pressure. As can be seen from Figure 7, which shows various fits of an $n$-butane adsorption isotherm, and from the data in Table 1, satisfactory fits of the measured data in Figures $5 \mathrm{a}$ and $5 \mathrm{~b}$ were not achieved unless the order of the function, $1 / n$, was not constrained:

$$
N=\frac{N_{0}(K p)^{1 / n}}{1+(K p)^{1 / n}}
$$
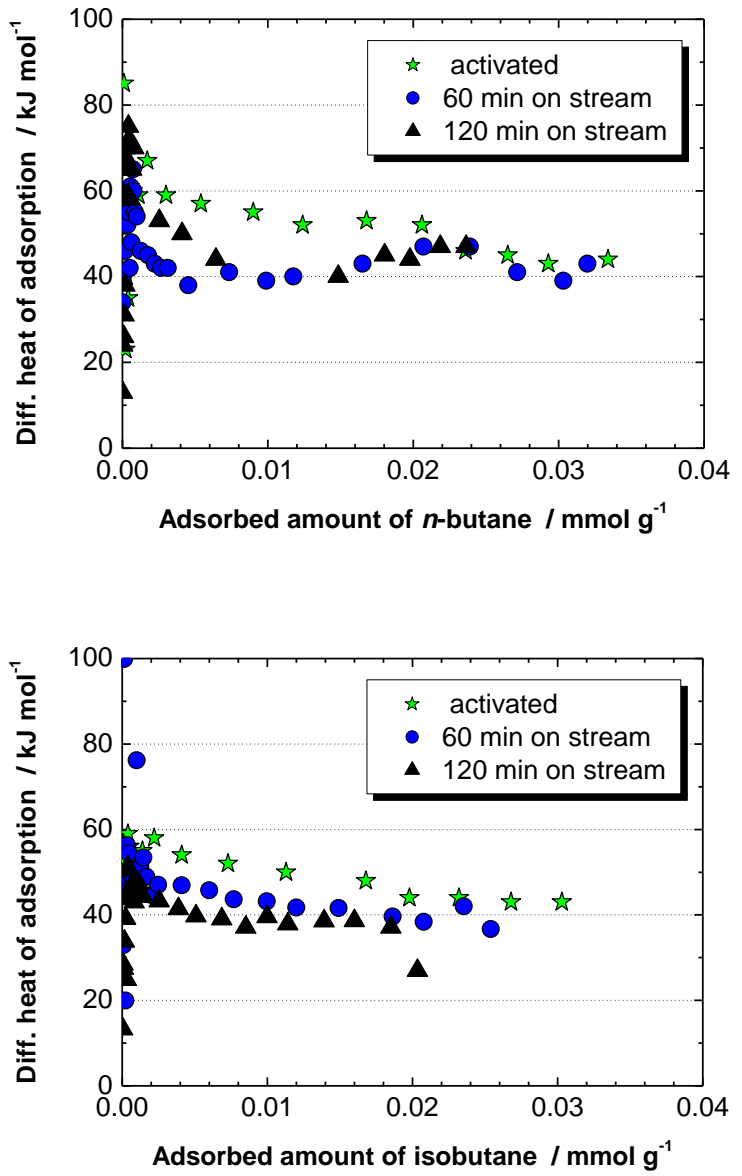

Fig. 6: Differential heats of butane adsorption at $313 \mathrm{~K}$ on sulfated zirconia catalysts adjusted to various stages of activity by butane isomerization in the calorimeter cell for $60 \mathrm{~min}$ or $120 \mathrm{~min}$. a) $n$ butane adsorption; b) isobutane adsorption.

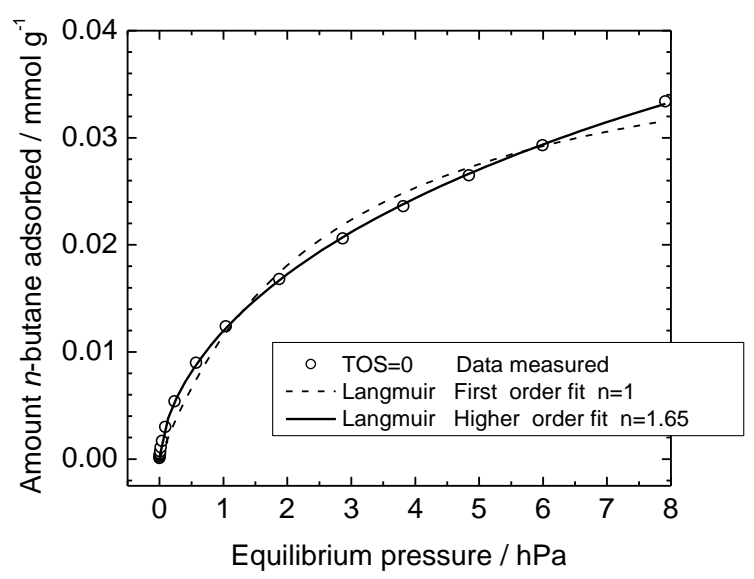

Fig. 7: Langmuir fits of the isotherm obtained for $n$-butane adsorption at $313 \mathrm{~K}$ on activated sulfated zirconia. Symbols: data points; dotted line: first order Langmuir equation; dashed line: higher order Langmuir equation. 
Table 1: Langmuir fit results of butane adsorption isotherms at $313 \mathrm{~K}$

\begin{tabular}{|c|c|c|c|c|c|c|c|}
\hline & \multicolumn{3}{|l|}{ First-order fit } & \multicolumn{4}{|c|}{ Higher order fit } \\
\hline & $N_{0}\left(\mathrm{mmol} \mathrm{g}^{-1}\right)$ & $K\left(\mathrm{hPa}^{-1}\right)$ & $R^{2}$ & $n$ & $N_{0}\left(\mathrm{mmol} \mathrm{g}^{-1}\right)$ & $K\left(\mathrm{hPa}^{-1}\right)$ & $R^{2}$ \\
\hline \multicolumn{8}{|c|}{$\begin{array}{l}\text { n-Butane adsorption } \\
\text { Time on stream (min) }\end{array}$} \\
\hline $\begin{array}{l}0 \\
60 \\
120\end{array}$ & $0.042(2)$ & $0.38(5)$ & 0.99182 & $\begin{array}{l}1.65(3) \\
1.37(2) \\
1.06(2)\end{array}$ & $\begin{array}{l}0.113(10) \\
0.076(7) \\
0.046(6)\end{array}$ & $\begin{array}{l}0.030(7) \\
0.088(6) \\
0.162(9)\end{array}$ & $\begin{array}{l}0.99983 \\
0.99989 \\
0.99994\end{array}$ \\
\hline \multicolumn{8}{|c|}{$\begin{array}{l}\text { Isobutane adsorption } \\
\text { Activation } T(\mathrm{~K})\end{array}$} \\
\hline $\begin{array}{l}473 \\
573 \\
723\end{array}$ & & & & $\begin{array}{l}1.38(3) \\
1.47(4) \\
1.61(3) \\
1.62(6)\end{array}$ & $\begin{array}{l}0.119(7) \\
0.112(9) \\
0.134(8) \\
0.15(2)\end{array}$ & $\begin{array}{l}0.08(1) \\
0.11(2) \\
0.12(2) \\
0.09(3)\end{array}$ & $\begin{array}{l}0.99979 \\
0.99965 \\
0.99974 \\
0.9997\end{array}$ \\
\hline \multicolumn{8}{|c|}{ Time on stream (min) } \\
\hline $\begin{array}{l}0 \\
60 \\
120\end{array}$ & $\begin{array}{l}0.042(2) \\
0.042(2) \\
0.044(2)\end{array}$ & $\begin{array}{l}0.37(5) \\
0.21(2) \\
0.12(1)\end{array}$ & $\begin{array}{l}0.99349 \\
0.99614 \\
0.99782\end{array}$ & $\begin{array}{l}1.58(3) \\
1.38(1) \\
1.29(2)\end{array}$ & $\begin{array}{l}0.133(15) \\
0.116(5) \\
0.171(41)\end{array}$ & $\begin{array}{l}0.024(6) \\
0.026(2) \\
0.011(4)\end{array}$ & $\begin{array}{l}0.99988 \\
0.99996 \\
0.99980\end{array}$ \\
\hline
\end{tabular}

where $\mathrm{N}$ and $\mathrm{N}_{0}$ are the actual and the monolayer coverage in $\mathrm{mmol}^{-1}, \mathrm{p}$ is the equilibrium pressure, and $\mathrm{K}$ is the adsorption constant.

A value of one for $n$ is indicative of non-dissociative adsorption, whereas a value of two is typical of dissociative adsorption. The adsorption of $n$ - or isobutane on sulfated zirconia thus cannot be described with a simple first order Langmuir equation; this statement is valid for the states obtained by varying the activation temperature and for the initial reaction phase (Table 1).

\subsection{Effect of activation}

Activation of sulfated zirconia is achieved through thermal treatment in various atmospheres. Temperatures reported to produce the best catalytic performance span a range from 523-573 [23] to $923 \mathrm{~K}$ [22]. Song and Kydd [24] showed that the choice of the atmosphere, air or helium, does not affect the catalytic activity in $n$-butane conversion. One of the main effects of the pretreatment is partial removal of adsorbed water. Several authors showed that a particular amount of water is necessary for good performance. The optimal amount is debated; Kobe et al. [44] proposed $75 \mu \mathrm{mol} \mathrm{g}{ }^{-1}$ whereas Song and Kydd [23] reported $200 \mu \mathrm{mol} \mathrm{g}{ }^{-1}$. Morterra et al. [45] showed that the number of Brønsted sites decreases with progressing dehydration, with Lewis acid sites formed in turn. The remaining Brønsted acid sites become stronger with further dehydration through the effect of adjacent Lewis acid sites [46]. Bobricheva et al. [47] observed the formation of $\mathrm{F}^{+}$ centers on the surface of sulfated zirconia after activation at temperatures larger than $573 \mathrm{~K}$ in vacuo; and one catalyst exhibited $\mathrm{Zr}^{3+}$ surface centers after heating to $873 \mathrm{~K}$. There are thus a variety of potential adsorption sites for butane available on sulfated zirconia. However, Klose et al. [48] investigated sulfated zirconia that had been activated at 723 $\mathrm{K}$ using IR spectroscopy and found that $\mathrm{OH}$ groups were disturbed after adsorption of $10 \mathrm{hPa} n$-butane at room temperature. These data were recorded under conditions close to those applied here and, given the similar chemical nature of $n$ - and isobutane, at least a fraction of the adsorbed isobutane in the calorimetry experiment should be located on $\mathrm{OH}$ groups. This interpretation is further corroborated by the differing amounts that are adsorbed after activation on the two investigated catalysts. At the same equilibrium pressure, the material calcined at $823 \mathrm{~K}$ adsorbs about twice as much isobutane as the material calcined at $873 \mathrm{~K}$ (cf. Figs. 4a and 5b). This difference cannot be explained by the surface areas, which are in the same range (100 and $\left.86 \mathrm{~m}^{2} \mathrm{~g}^{-1}\right)$; rather, the higher calcination temperature will lead to a loss of hydroxyl groups as shown earlier by Klose et al. [48]. Hence, the lower amount of adsorbed isobutane after calcination at higher temperature is a result of a lower $\mathrm{OH}$ group density.

With increasing activation temperature, adsorption sites become available that interact more strongly with isobutane and lead to an increase in coverage in the investigated pressure range. The exponent in the Langmuir equation decreases from $1 / 1.4$ to 1/1.6. The results are consistent with a distribution of sites on the surface. One of the adsorbed states, which becomes more abundant with increasing activation temperature, probably requires two sites, which results in the exponent approaching 1/2. The formation of this state releases slightly higher heats. The exponent obtained for $n$-butane on the catalyst activated at $723 \mathrm{~K}$ is 1.7 , which suggests a similar adsorption scenario as for isobutane.

The heats of adsorption indicate that the interaction of sulfated zirconia with $n$ - and isobutane is much weaker than with strong bases such as ammonia, which produces initial heats of adsorption of $150-165 \mathrm{~kJ} \mathrm{~mol}^{-1}$ [49], according to some reports even larger than $200 \mathrm{~kJ} \mathrm{~mol}^{-1}$ [29,50]. Gonzalez et al. [21] reported that the heats of adsorption of ammonia do not vary with the activation temperature whereas the catalytic activity does; hence, ammonia is not a suitable probe for critical variations in surface state.

The heats of 60-40 and $60-45 \mathrm{~kJ} \mathrm{~mol}^{-1}$ released during adsorption of $n$ - or isobutane, are consistent with values reported earlier by González et al. [21] who determined 
heats of adsorption of $n$ - and isobutane on sulfated zirconia of 57-36 and 58-30 $\mathrm{kJ} \mathrm{mol}^{-1}$, respectively. The adsorption of $n$-butane on H-Mordenite and H-ZSM5, both typical solid acids, produces 58 or $50 \mathrm{~kJ} \mathrm{~mol}^{-1}$, respectively; a value of $52 \mathrm{~kJ} \mathrm{~mol}^{-1}$ is obtained for isobutane adsorption on either of the materials [51]. Interaction of alkanes with strongly acidic solids thus must not lead to high heats. The order of magnitude of the heats also suggests that desorption from the majority of sites is facile. In summary, uptake, heats and curve shape are very similar for $n$ - and isobutane.

The higher order Langmuir fit of the activated catalyst $(0 \mathrm{~min})$ was used to extrapolate the coverage to the reaction partial pressure. About $0.037 \mathrm{mmol} \mathrm{g}^{-1}$ would be adsorbed at $313 \mathrm{~K}$ and $1.0 \mathrm{kPa} n$-butane. Unless the adsorption is strongly activated, the coverage will be even lower at the reaction temperature of $378 \mathrm{~K}$. The concentration of sulfate groups in the sample is $0.94 \mathrm{mmol} \mathrm{g}^{-1}$. Through comparison of this value with the projected coverage it can be concluded that the majority of the sulfate groups does not constitute adsorption sites. The percentage of active sulfate groups may vary depending on sulfate content and preparation method; nonetheless our results are qualitatively consistent with reports by $\mathrm{Li}$ and Gonzalez [52], who found only $14 \%$ of the sulfate groups to be active.

\subsection{Surface alteration during induction period}

The calorimetry experiments performed after 0,60 , and $120 \mathrm{~min}$ of reaction showed overall decreasing adsorbed amounts and heats with increasing time on stream and isobutane formation rate. The trend is not steady for $n$ butane adsorption with the experiment after 60 min giving lower heats but an equal number of sites as obtained for the fresh catalyst; however, the start-up of this catalyst in the 60-min run (Fig. 3, right panel) was not very promising. Formation of isobutane through isomerization of $n$-butane, as was observed for the catalyst in its active state, is only slightly exothermic by about $5 \mathrm{~kJ} \mathrm{~mol}^{-1}$ and will not affect the evolving heats greatly. For the series of experiments with isobutane, the trend of decreasing amounts is unambiguous and over a wide range, decreasing heats are observed with increasing time on stream. The results demonstrate that that at least two types of site must exist on the surface of sulfated zirconia, which behave differently during $n$ butane isomerization. One type of site does not change during the reaction and is characterized by a differential heat for $n$-butane and isobutane adsorption of ca. $40 \mathrm{~kJ} \mathrm{~mol}^{-}$ ${ }^{1}$. A group of sites in the coverage range from $2-20 \mu \mathrm{mol} \mathrm{g}^{-}$ ${ }^{1}$ with heats of adsorption of initially $50-60 \mathrm{~kJ} \mathrm{~mol}^{-1}$ disappears at least in part as the catalyst is exposed to the $n$ butane feed. The behavior of a small quantity of sites at coverages below $2 \mu \mathrm{mol} \mathrm{g}{ }^{-1}$ remains difficult to interpret because of the large scatter of data points. In principle, the very high and low heats in this range may be the result of exothermic and endothermic secondary reactions (other than isomerization) that follow the adsorption. If, for example, some oxidative dehydrogenation was occurring at $313 \mathrm{~K}$, it could produce as much as $67 \mathrm{~kJ} \mathrm{~mol}^{-1}$ [8]. If the $20 \mu \mathrm{mol} \mathrm{g} \mathrm{g}^{-1}$ sites that are distinguished by higher heats of adsorption were the sites on which activation of the butane occurred and chain carriers were formed, then the number of active intermediates should correspond to the number of these sites. Kim et al. [53] calculated the concentration of active intermediates to be $5-10 \mu \mathrm{mol} \mathrm{g}^{-1}$; Li et al. [54] estimated $5 \mu \mathrm{mol} \mathrm{g}^{-1}$ sec.-butyl ions, which are the product precursors. These concentrations match well the number of sites with the highest heats of adsorption.

More information about the nature of the sites and the adsorption and reaction process can be extracted from the shape of the isotherms. The value of $n$ is about 1.6 for adsorption of either butane on the freshly activated catalyst and decreases with increasing time on stream. In fact, during the induction period, all of the sites leading to $n>1$ are consumed as far as $n$-butane adsorption is concerned (Table 1). The disappearing sites must be the centers on which the active surface species are generated that serve as chain carriers for the isomerization.

There are two reasons as to why the sites with the highest heats could disappear during the induction period: they could be stoichiometrically converted, or they could be blocked by side products or strongly held intermediates. Previous research has shown that water is formed during the initial phase of butane conversion on sulfated zirconia $[13,48,55]$, and, given the mild reaction temperature of 378 $\mathrm{K}$, water would be retained on the surface and could block the sites. For this scenario speaks further that the changes observed in isotherms and heats exhibit a reverse trend to the alterations induced during activation with increasingly higher temperature. These alterations were explained with progressive dehydration; and hence, rehydration should reverse them. However, the formation of water requires that oxygen is transferred from the catalyst, and evidence has been put forth that shows that sulfate species are reduced $[13,48]$. Since oxidizing agents are absent in the feed, such redox reaction is irreversible and would lead to the permanent destruction of the according sites. An intermediate created from the oxidative dehydrogenation is butene, which is retained up to $380 \mathrm{~K}$ on the surface [13] and thus could also block sites. As a third possibility, carbonaceous deposits could block sites, however, Ahmad et al. [17] reported that such deposits are mainly detected after the catalyst has passed through its state of highest activity. In summary, oxidative dehydrogenation provides three reasons for the loss of sites. Moreover, it has been suggested that this initiation reaction is responsible for the induction period [8]. The observed adsorption data are thus consistent with a scenario of an initiation reaction that results in the consumption of sites.

If the isomerization reaction proceeded via a Langmuir-Hinshelwood mechanism, then the equation for the adsorption isotherm would be integrated into the rate law. To check whether the derived functions are reflected in the rate laws, the literature was consulted. Ma et al. [58] found 
$n$-butane isomerization on sulfated zirconia at temperatures below $333 \mathrm{~K}$ to follow a reversible first order LangmuirHinshelwood rate equation. At higher temperatures, higher selectivity to disproprotionation products indicated a bimolecular mechanism; for this situation, no rate law was formulated. Li et al. [54] also favored first order kinetics.

Zarkalis and Gates [57] investigated butane isomerization on iron- and manganese promoted sulfated zirconia. They found first as well as second order LangmuirHinshelwood equations to fit their data well; based on a slightly better fit they expressed a preference for the second order mechanism while stating that Eley-Rideal kinetics could not be ruled out. Liu et al. [58] obtained reaction orders between 1.3 and 1.6 in $n$-butane for isomerization on platinum-promoted sulfated zirconia, with the reaction order being dependent on the presence of $\mathrm{H}_{2}$. These data indicate that modification of the catalyst and the reaction conditions will affect the mechanism and the reaction order, and only the above listed data obtained with unmodified sulfated zirconia in absence of $\mathrm{H}_{2}$ are suitable for comparison.

After the induction period, that is, at $120 \mathrm{~min}$ on stream, simple first order Langmuir adsorption of $n$-butane is observed. The adsorption isotherms of the reactant on the most active surface of sulfated zirconia data are thus consistent with the reported rate laws. However, the fate of the molecules that are weakly adsorbed, probably on $\mathrm{OH}$ groups [48], is not so clear. These species may simply be irrelevant. Alternatively, they could react with neighboring intermediates, whose concentration may be solely a function of the available number of initiation sites rather than the gas phase reactant partial pressure, in an intermolecular reaction.

\section{Conclusions}

A protocol for the characterization of surface sites of catalysts in their active state by adsorption microcalorimetry was developed. A calorimeter cell was modified for use as a flow-type reactor, and the reaction behavior that is observed in a fixed-bed plug-flow reactor was reproduced.

\section{References}

[1] M. Hino, S. Kobayashi, K. Arata, J. Am. Chem. Soc. 101 (1979) 6439-6441.

[2] M. Hino, K. Arata, Chem. Comm. (1980) 851.

[3] K. Arata, Appl. Catal. A: General 146 (1996) 3.

[4] X. Song, A. Sayari, Cat. Rev. Sci. Eng., 38 (1996) 329.

[5] G.D. Yadav, J.J. Nair, Microp. Mesop. Mater. 33 (1999) 1.

[6] C.-Y. Hsu, C.R. Heimbuch, C.T. Armes, B.C. Gates, Chem. Comm. (1992) 1645.

[7] F.C. Lange, T.-K. Cheung, B.C. Gates, Catal. Lett. 41 (1996) 95-99.

[8] X. Li, K. Nagaoka, L.J. Simon, J.A. Lercher, S. Wrabetz, F.C. Jentoft, C. Breitkopf, S. Matysik, H. Papp, J. Catal. 230 (2005) 214-225.
After the catalyst performed isomerization for a particular time span, the cell was evacuated and adsorption experiments were performed. The novel technique is limited when investigating a reaction that occurs at a temperature not far above the lowest applicable temperature in the calorimeter because in this case adsorption may be followed by reaction. Calorimetric data thus may be obscured and, if the number of molecules in the system changes through the reaction, the number of adsorbed molecules can no longer be accurately determined via pressure measurement. Indeed, isomerization occurred in the calorimeter cell on samples in their active state; but this reaction does not change the number of molecules.

The surface of activated sulfated zirconia was characterized by at least two different sites for $n$-butane adsorption. Sites that are populated at coverages above 20 $\mu$ mol g ${ }^{-1}$ produce heats of about $40 \mathrm{~kJ} \mathrm{~mol}^{-1}$ and remain largely unchanged during the catalytic experiment. A group of sites, about $20 \mu \mathrm{mol} \mathrm{g}{ }^{-1}$, produces $50-60 \mathrm{~kJ} \mathrm{~mol}^{-1}$ and perhaps even higher heats. These sites disappear during the induction period of the $n$-butane isomerization and are presumed to be the initiation sites where reaction chain carriers are generated; their number corresponds to reported concentrations of intermediates.

\section{Acknowledgement}

Financial support from Deutsche Forschungsgemeinschaft through the priority program No. 1091 "Bridging the Gap in Heterogeneous Catalysis", project JE 267/01 is acknowledged. -The authors would like to thank the project partners Cornelia Breitkopf and Helmut Papp at the University of Leipzig for providing one of the sulfated zirconia materials. Alexander H.P. Hahn is acknowledged for preparing one of the samples and the Max Planck Society for long-term financial support of the project.

[9] A. Hahn, T. Ressler, R.E. Jentoft, F.C. Jentoft, Chem. Comm. (2001) 537

[10] A.H.P. Hahn, R.E. Jentoft, T. Ressler, G. Weinberg, R. Schlögl, F.C. Jentoft, J. Catal. 236 (2005) 324-334.

[11] B.S. Klose, R.E. Jentoft, A. Hahn, T. Ressler, J. Kröhnert, S. Wrabetz, X. Yang, F.C. Jentoft, J. Catal. 217 (2003) 487490.

[12] M.A. Coelho, W.E. Alvarez, E.C. Sikabwe, R.L. White, D.E. Resasco, Catal. Today 28 (1996) 415-429.

[13] X. Li, K. Nagaoka, L.J. Simon, R. Olindo, J.A. Lercher, A. Hofmann, J. Sauer, J. Am. Chem. Soc. 127 (2005) $16159-16166$ 
[14] F.R. Chen, G. Coudurier, J. Joly, J.C Védrine, J. Catal. 143 (1993) 616.

[15] B. Li, R.D. Gonzalez, Appl. Catal. A: General 174 (1998) 109-119.

[16] D. Spielbauer, G.A.H. Mekhemer, E. Bosch, H. Knözinger, Catal. Lett. 36 (1996) 59.

[17] R. Ahmad, J. Melsheimer, F.C. Jentoft, R. Schlögl, J. Catal. 218 (2003) 365.

[18] G.J. Hutchings, A. Desmartin-Chomel, R. Olier, J.-C. Volta, Nature 368 (1994) 41-45.

[19] J.S. Lee, K.H. Lee, S.Y. Lee., Y.G. Kim, J. Catal. 144 (1993) 414-424.

[20] X. Song, A. Sayari, Catal. Rev.- Sci. Eng. 38 (1996) 329-412.

[21] M.R. González, K.B. Fogash, J.M. Kobe, J.A. Dumesic, Catal. Today 33 (1997) 303-312.

[22] C.R. Vera, J.M. Parera, J. Catal. 165 (1997) 254.

[23] S.X. Song, R.A. Kydd, J. Chem. Soc. Faraday Trans. 94 (1998) 1333.

[24] S.X. Song, R.A. Kydd, Catal. Lett. 51 (1998) 95-100.

[25] A. Auroux, Y. Ben Taarit, Thermochim. Acta 122 (1987) 63.

[26] L.C. Jozefowicz, H.G. Karge, E. Vasilyeva, J.B. Moffat, Microp. Mater. 1 (1993) 313.

[27] . Jänchen, M.P.J. Peeters, J.H.M.C. Van Wolput, J.P. Wolthuizen, J.H.C. Van Hoof, U. Lohse, J. Chem. Soc. Faraday Trans. 90 (1994) 1033.

[28] V. Rakic, V. Dondur, U. Moic, D. Jovanovic, Topics in Catal. 19 (2002) 241

[29] R.S. Drago, N. Kob, J. Phys. Chem. B. 101 (1997) 3360.

[30] V. Quaschning, A. Auroux, J. Deutsch, H. Lieske, E. Kemnitz, J. Catal. 203 (2001) 426.

[31] V. Bolis, G. Magnacca, G. Cerrato, C. Morterra, Thermochim. Acta 379 (2001) 147-161.

[32] V. Bolis, G. Magnacca, G. Cerrato, C. Morterra, Topics in Catal. 19 (2002) 259.

[33] J.C. Vartuli, J.G. Santiesteban, P. Traverso, N. CardonaMartinez, C.D. Chang, S.A. Stevenson, J. Catal. 187 (1998) 131.

[34] J. Kotrla, L. Kubelková, C.-C. Lee, R.J. Gorte, J. Phys. Chem. B 102 (1998) 1437.

[35] O. Kresnawahjuesa,G.H. Kühl, R.J. Gorte, C.A. Quierini, J. Catal. 210 (2002) 106.

[36] E.N. Coker, C. Jia, H.G. Karge, Langmuir 16 (2000) 1205.

[37] L.C. Josefowicz, H.G. Karge, E.N. Coker, J. Phys. Chem. 98 (1994) 8053.

[38] E.N. Coker, H.G. Karge, Rev. Sci. Instrum. 68 (1997) 4521.
[39] J.O. Hirschfelder, C.F. Curtiss, R. Byron Bird, Molecular Theory of Gases and Liquids, J. Wiley \& Sons, New York, 1954.

[40] H. Liu, V. Adeeva, G.D. Lei, W.M.H. Sachtler, J. Molec. Catal. A: Chemical 100 (1995) 35.

[41] D'Ans Lax, Taschenbuch für Chemiker und Physiker (Handbook for chemists and physicists), $4^{\text {th }}$ ed., Vol. II, Organic compounds, Springer, Berlin, 1983.

[42] D.J. Parillo, R.J. Gorte, Thermochim. Acta 312 (1998) 125-132.

[43] I. Langmuir, J. Am. Chem. Soc. 38 (1916) 2221.

[44] J.M. Kobe, M.R. González, K.B. Fogash, J.A. Dumesic, J. Catal. 164 (1996) 459-466.

[45] C. Morterra, G. Cerrato, C. Emanuel, V. Bolis, J. Catal. 142 (1993) 349-367.

[46] J.H. Lunsford, H. Sang, S.M. Campbell, C.-H. Liang, R.G. Anthony, Catal. Lett. 27 (1994) 305-314.

[47] I.V. Bobricheva, I.A. Stavitsky, V.K. Yermolaev, N.S. Kotsarenko, V.P. Shmachkova, D.I. Kochubey, Catal. Lett. 56 (1998) 23-27.

[48] B.S. Klose, F.C. Jentoft, R. Schlögl, I.R. Subbotina, V.B. Kazansky, Langmuir 21 (2005) 10564-10572.

[49] K.B. Fogash, G. Yaluris, M.R. González, P. Ouraipryvan, D.A. Ward, E.I. Ko, J.A. Dumesic, Catal. Lett. 32 (1995) 241-251.

[50] M.L. Occelli, D.A. Schiraldi, A. Auroux, R.A. Keogh, B.H. Davis, Appl. Catal. A: General 209 (2001) 165-177.

[51] F. Eder, M. Stockenhuber, J.A. Lercher, Stud. Surf. Sci. Catal. 97 (1995) 495-500.

[52] B. Li, R.D. Gonzalez, Appl. Catal. A: General 165 (1997) 291-300.

[53] S.Y. Kim, J.G. Goodwin Jr., D. Galloway, Catal. Today 63 (2000) 21-32.

[54] X. Li, K. Nagaoka, L.J. Simon, R. Olindo, J.A. Lercher, J. Catal. 232 (2005) 456-466.

[55] B.S. Klose, F.C. Jentoft, R. Schlögl, J. Catal. 233 (2005) 6880

[56] Z. Ma, Y. Zou, W. Hua, H. He, Z. Gao, Topics in Catal. 35 (2005) 141-153.

[57] A.S. Zarkalis, C.-Y. Hsu, B.C. Gates, Catal. Lett. 29 (1994) 235.

[58] H. Liu, V. Adeeva, G.D. Lei, W.M.H. Sachtler, J. Molec. Catal. A: Chemical 100 (1995) 35-48. 